CZASOPISMO INŻYNIERII LĄDOWEJ, ŚRODOWISKA I ARCHITEKTURY JOURNAL OF CIVIL ENGINEERING, ENVIRONMENT AND ARCHITECTURE

JCEEA, t. XXXIV, z. 64 (3/I/17), lipiec-wrzesień 2017, s. 447-460, DOI: 10.7862/rb.2017.137

\author{
Marian GIŻEJOWSKI ${ }^{1}$ \\ Radosław SZCZERBA ${ }^{2}$ \\ Marcin GAJEWSKI ${ }^{3}$
}

\title{
WPLYW IMPERFEKCJI NA TECHNICZNE ZWICHRZENIE STALOWYCH BELEK WALCOWANYCH I SPAWANYCH
}

\begin{abstract}
W pracy przedstawiono zagadnienie wpływu imperfekcji materiałowych i geometrycznych na techniczne zwichrzenie stalowych belek walcowanych i spawanych poddanych jednokierunkowemu zginaniu względem osi większej bezwładności przekroju $y$ - $y$. Obliczenia metodą elementów skończonych przeprowadzono w odniesieniu do belek walcowanych na gorąco, wykonanych z kształtowników szerokostopowych HEB i wąskostopowych IPE oraz belek spawanych o takich samych proporcjach przekroju. Analizowano elementy o wstępnym wygięciu odpowiadającym pierwszej formie zwichrzenia oraz pierwszej formie giętnej względem osi mniejszej bezwładności przekroju $z-z$. Naprężenia resztkowe po walcowaniu i spawaniu elementów modelowano z użyciem wstępnych pól naprężeń. Wykonano geometrycznie i materiałowo nieliniowe analizy GMNIA. Do obliczeń numerycznych wykorzystano program metody elementów skończonych ABAQUS/Standard.
\end{abstract}

Słowa kluczowe: stalowe belki dwuteowe spawane i walcowane, naprężenia rezydualne, imperfekcje geometryczne, zwichrzenie, MES, GMNIA

\section{Wprowadzenie}

Elementy stalowych konstrukcji realnych obarczone są imperfekcjami geometrycznymi oraz materiałowymi, które są pozostałością procesu wytwarzania tych elementów. W niniejszej pracy autorzy w praktyczny sposób przedstawili wybrane podejścia do modelowania wpływu różnego typu imperfekcji na nośność stalowych belek poddanych jednokierunkowemu zginaniu. W tym celu wykonano analizy GMNIA przy użyciu metody elementów skończonych.

\footnotetext{
${ }^{1}$ Autor do korespondencji / corresponding author: Marian Giżejowski, Politechnika Warszawska, al. Armii Ludowej 16, 00-637 Warszawa, tel.: +48 22234 6554, m.gizejowski@il.pw.edu.pl

2 Radosław Szczerba, Politechnika Warszawska, al. Armii Ludowej 16, 00-637 Warszawa, tel.: +48 22234 6261, r.szczerba@il.pw.edu.pl

${ }^{3}$ Marcin Gajewski, Politechnika Warszawska, al. Armii Ludowej 16, 00-637 Warszawa, tel.: +48 22234 5164, m.gajewski@il.pw.edu.pl
} 


\section{Podejścia przyjęte w analizie elementów imperfekcyjnych}

\subsection{Metoda zastępczych imperfekcji geometrycznych}

Zgodnie z normą projektowania konstrukcji stalowych PN-EN 1993-1-1 [1], pręty zginane można obliczać przy przyjęciu zastępczej imperfekcji geometrycznej, która całościowo uwzględnia wpływ wszystkich niedoskonałości na nośność elementu realnej konstrukcji stalowej. Analityczny opis zachowania się elementu imperfekcyjnego bazuje na modelu Ayrtona-Perry'ego elementu wstępnie wygiętego wg formy odpowiadającej stanowi krytycznemu, z zastępczą amplitudą wygięcia wg propozycji Maquoi-Rondala [2]. Wykorzystując zależności podane przez Rykaluka [3], amplitudę bocznego wygięcia przy zastępczej imperfekcji geometrycznej można zidentyfikować jako:

$$
e_{0, L T}=\frac{\alpha_{L T}\left(\bar{\lambda}_{L T}-0,2\right)}{\frac{M_{c y, R k}}{B_{c, R k}}\left[1+\frac{N_{c r, z}}{M_{c r}}\left(\frac{B_{c, R k}}{M_{c z, R k}}-\frac{G I_{T}}{M_{c r}}\right)\right]},
$$

gdzie: $B_{c, R k}$ - bimomentowa nośność charakterystyczna przekroju, $M_{c y, R k}-$ momentowa nośność charakterystyczna przekroju względem osi głównej $y-y, M_{c z, R k}-$ momentowa nośność charakterystyczna przekroju względem osi głównej $z-z$, $M_{c r}$ - moment krytyczny z LBA (liniowej teorii stateczności) [2], dotyczący idealnego modelu sprężystej belki lub rygla i wyznaczony, w wypadku czystego zginania, z zamkniętego rozwiązania równania różniczkowego stateczności belki modelowanej jako pręt cienkościenny Własowa o przekroju dwuteowym (w wypadku innych warunków obciążenia, przy wyznaczeniu momentu krytycznego należy odwołać się do przybliżonych rozwiązań analitycznych lub numerycznych); $\alpha_{L T}$ - parametr imperfekcji odniesiony do odpowiedniej krzywej zwichrzenia miarodajnej dla metody ogólnej sprawdzenia nośności przy zwichrzeniu (pozostałe oznaczenia zgodnie z [1]).

Na rysunku 1. przedstawiono kształt zastępczej imperfekcji geometrycznej, odpowiadający pierwszej postaci zwichrzenia (globalnej utraty stateczności) pręta przy czystym zginaniu oraz amplitudę $e_{0, L T} \mathrm{~W}$ przekroju znajdującym się w środku rozpiętości rozpatrywanego elementu. Na rysunku 2. pokazano przykładowo wartości zastępczych amplitud imperfekcji w funkcji smukłości belki przy zawichrzeniu, w odniesieniu do elementów walcowanych na gorąco o przekroju HEB 300 i elementów spawanych o przekroju HW 300 (proporcje przekroju takie same jak w przypadku HEB 300). Wyniki uzyskano przy przyjęciu plastycznych i sprężystych nośności przekrojów zgodnie z wyrażeniem (1). 


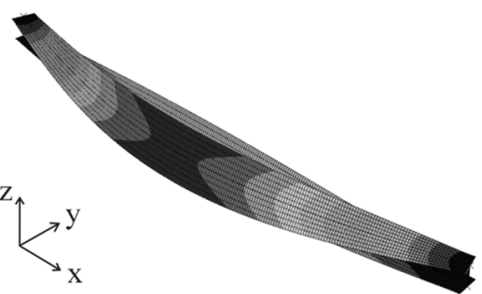

a)

Rys. 1. Zastępcza imperfekcja geometryczna; a) pierwsza postać zwichrzenia (globalnej utraty stateczności) przy czystym zginaniu; b) amplituda imperfekcji $e_{0, L T}$

Fig. 1. The equivalent geometrical imperfection; a) the lowest buckling mode corresponding to lateral-torsional buckling; b) the imperfection amplitude $e_{0, L T}$

a)
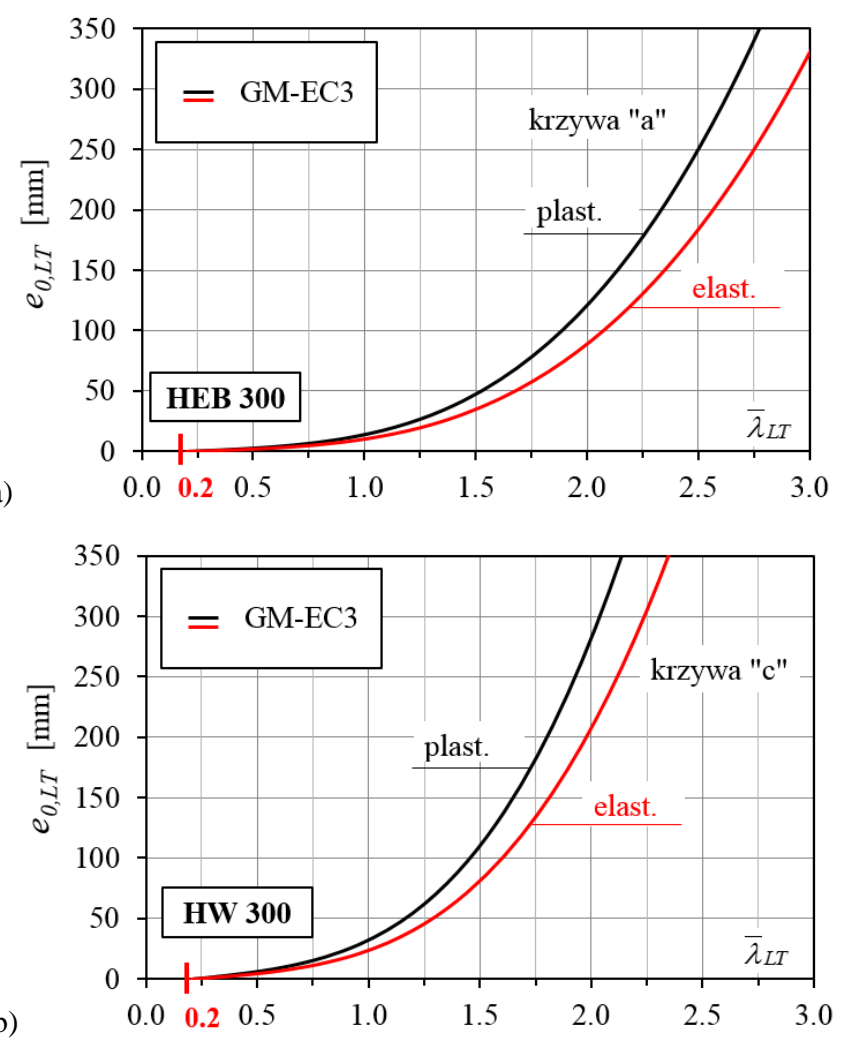

Rys. 2. Amplituda zastępcza $e_{0, L T} \mathrm{w}$ funkcji smukłości belki; a) HEB 300; b) HW 300

Fig. 2. Equivalent amplitude $e_{0, L T}$ as a function of beam slenderness; a) HEB 300; b) HW 300 


\subsection{Rozdzielenie imperfekcji materiałowych i geometrycznych}

W odniesieniu do imperfekcji materiałowych rozważono naprężenia rezydualne (resztkowe) pozostające w elemencie po zakończeniu procesu jego wytwarzania. Standardowe rozkłady naprężeń rezydualnych w przypadku elementów walcowanych na gorąco przedstawiono na rys. 3., rozróżniając dystrybucję naprężeń dla przekrojów szerokostopowych oraz wąskostopowych. W analizie GMNIA naprężenia rezydualne modelowano z użyciem opcji wstępnych pól naprężeń. Naprężenia wstępne $\sigma_{R}$ zadawano w kierunku osi podłużnej obliczanego elementu (oznaczone $S_{x x}$, zgodnie z rys. 4.).

$\mathrm{Na}$ rysunku 5. przedstawiono uproszczony rozkład naprężeń resztkowych w przypadku elementów spawanych [4]. Zasięg strefy wpływu ciepła HAZ (Heat-Affected Zone) zależy od przyjętej metody spawania MAG (Metal Active Gas - spawanie elektrodą topliwą w osłonie gazów aktywnych; na wykresie 5b zaznaczono linią ciągłą) lub SAW (Submerged Arc Welding - spawanie łukiem krytym; na wykresie 5b zaznaczono linią przerywaną) oraz od referencyjnej wartości granicy plastyczności łączonych elementów. Zasięg naprężeń rozciągających w pasach wynosi $c_{2}=c_{w}+0,5 t_{w}$, natomiast w środniku $c_{w}$. Wartości współczynników $\gamma$ oraz $\delta$ na ściskanych odcinkach ścianek oblicza się z warunku równowagi naprężeń $w$ przekroju. $W$ tab. 1 przedstawiono parametry wpływające na rozkład naprężeń rezydualnych w odniesieniu do przekrojów HW 300 oraz IW 500 (proporcje przekroju takie same jak w przypadku IPE 500) przy przyjęciu różnych metod spawania (MAG i SAW) oraz gatunków stali konstrukcyjnej (stal konwencjonalna S355 oraz stal o podwyższonej granicy plastyczności S 690). Wyniki uzyskano przy stosunku pola powierzchni spoin do sumy grubości łączonych ścianek $A_{\mathrm{w}} / \Sigma t=1,2$.

Imperfekcje geometryczne przyjęto jako wstępne wygięcia prętów względem osi mniejszej bezwładności przekroju $z-z$, o wartości amplitudy na poziomie tolerancji wytwarzania elementów walcowanych [5]: 3L/2000 i L/1000, w odniesieniu do IPE 500 i HEB 300, a także elementów spawanych [6]: L/750.

a)

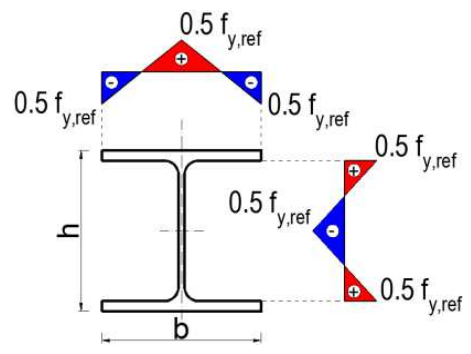

b)

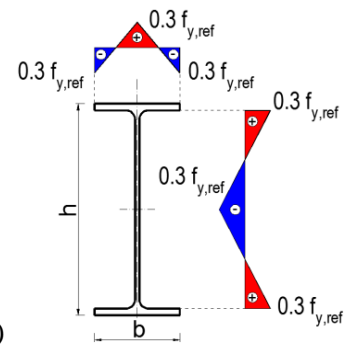

Rys. 3. Standardowy rozkład naprężeń rezydualnych w przypadku elementów walcowanych na gorąco; a) przekroje szerokostopowe, b) przekroje wąskostopowe

Fig. 3. Standard residual stress patterns in case of rolled sections; a) wide flange sections, b) narrow flange sections 


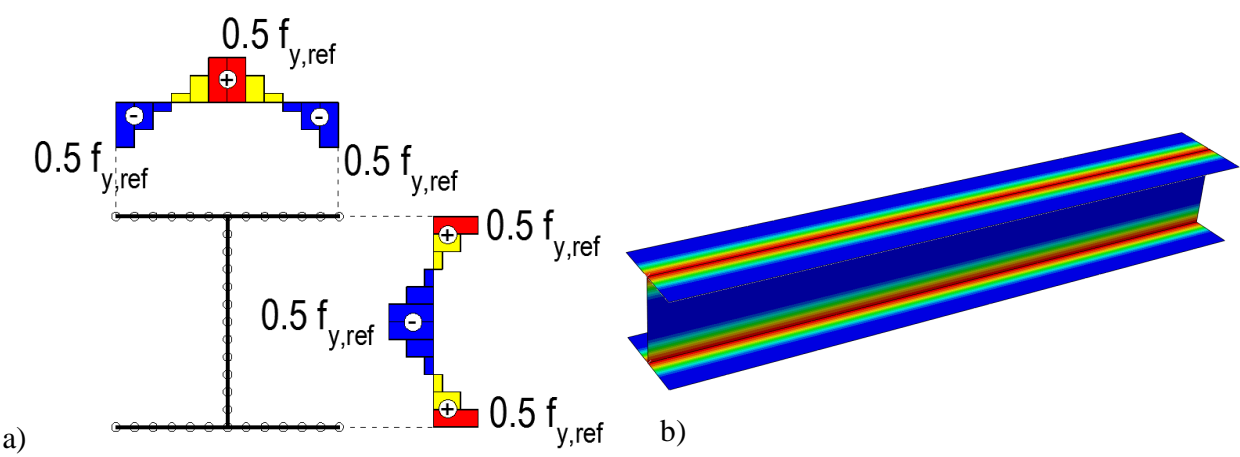

Rys. 4. Liniowo zmienne naprężenia rezydualne wg rys. 3a) modelowane jako zastępcze pole naprężeń wstępnych o schodkowo zmiennej rzędnej $\left(S_{x x}\right)$

Fig. 4. Residual stress distribution according to Fig. 3a) modelled as the equivalent stepped initial stress field $\left(S_{x x}\right)$
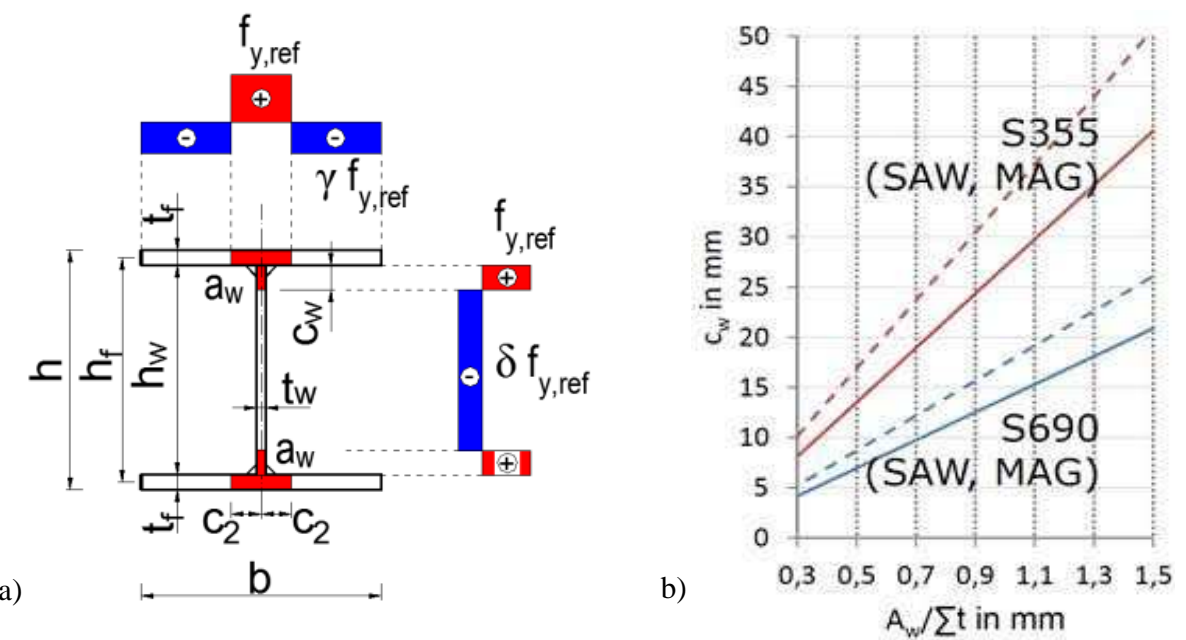

Rys. 5. Uproszczony rozkład naprężeń rezydualnych w zależności od metody spawania MAG lub SAW zgodnie z [4]; a) dystrybucja naprężeń; b) wykres zależności parametru $c_{w}$

Fig. 5. Simplified residual stress distribution dependent upon the welding technology MAG or SAW according to [4]; a) stress block; b) evaluation of HAZ geometric parameter $c_{w}$ 
Tabela 1. Parametry wpływające na rozkład naprężeń rezydualnych w przypadku $A_{\mathrm{w}} / \Sigma t=1,2$ i w odniesieniu do różnych przekrojów oraz metod spawania (zgodnie z rys. 5.)

Table 1. Parameters of residual stresses distribution in case of $A_{\mathrm{w}} / 2 t=1,2$ with respect to different sections and welding technologies (according to Fig. 5.)

\begin{tabular}{|c|c|c|c|c|c|}
\hline \multirow{2}{*}{$\begin{array}{c}\text { Zasięg stref } \\
\text { wpływu ciepła }\end{array}$} & \multirow{2}{*}{ Gatunek stali } & \multicolumn{2}{|c|}{ MAG } & \multicolumn{2}{|c|}{ SAW } \\
\hline & & HW 300 & IW 500 & HW 300 & IW 500 \\
\hline \multirow{2}{*}{$\begin{array}{c}c_{w}+0,5 t_{f} \\
{[\mathrm{~mm}]}\end{array}$} & S 355 & 42,0 & 40,5 & 50,1 & 48,6 \\
\hline & S 690 & 26,2 & 24,7 & 30,4 & 28,9 \\
\hline \multirow{2}{*}{$\begin{array}{c}\boldsymbol{c}_{\mathbf{2}} \\
{[\mathrm{mm}]}\end{array}$} & S 355 & 38,0 & 37,6 & 46,1 & 45,7 \\
\hline & S 690 & 22,2 & 21,8 & 26,4 & 26,0 \\
\hline \multirow{2}{*}{$\begin{array}{c}\gamma \\
{[-]}\end{array}$} & S 355 & 0,339 & 0,601 & 0,443 & 0,840 \\
\hline & S 690 & 0,174 & 0,279 & 0,213 & 0,351 \\
\hline \multirow{2}{*}{$\begin{array}{c}\delta \\
{[-]}\end{array}$} & S 355 & 0,426 & 0,201 & 0,554 & 0,251 \\
\hline & S 690 & 0,229 & 0,114 & 0,276 & 0,135 \\
\hline
\end{tabular}

\section{Symulacje MES zwichrzenia belek walcowanych}

Obliczenia zwichrzenia belek poddanych jednokierunkowemu zginaniu względem osi większej bezwładności przekroju $y-y$ przeprowadzono przy użyciu metody elementów skończonych i wykorzystaniu programu komputerowego ABAQUS/Standard. Jednoprzęsłowe belki modelowano z wykorzystaniem powłokowych elementów skończonych S4R o liniowych funkcjach kształtu. Zadane warunki brzegowe na końcach pręta umożliwiają liniowo-zmienną deplanację na długości pasów. Do obliczeń przyjęto sprężysto-plastyczny model stali o wzmocnieniu izotropowym i o małej wartości modułu wzmocnienia, równej E/1000 w celu uzyskania numerycznej stabilności rozwiązania. Szczegóły modelowania MES zostały przedstawione przez autorów w [7] i [8].

Nośności elementów wyznaczono przyjmując imperfekcje geometryczne o wartości zastępczej lub o wartości realnej, gdy w sposób jawny uwzględniono imperfekcje materiałowe. Rozkład naprężeń rezydualnych określono po przyjęciu $f_{y, r e f}=235 \mathrm{~N} / \mathrm{mm}^{2}$ oraz $f_{y, r e f}=355 \mathrm{~N} / \mathrm{mm}^{2}$. Analizie poddano elementy o przekrojach HEB 300 oraz IPE 500 wykonane ze stali S355. Wyniki symulacji MES porównano z wynikami otrzymanymi z metody ogólnej (oznaczono przez GM-EC 3) i porównano z krzywymi eurokodowymi. Krzywe eurokodowe skonstruowano w dwojaki sposób, przyjmując smukłość $\bar{\lambda}_{L T}$ na podstawie momentu krytycznego z rozwiązania liniowego problemu własnego (LEA) zaś smukłość

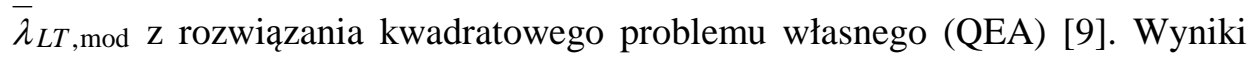
przeprowadzonych obliczeń MES w przypadku zwichrzonych belek walcowanych zamieszczono na rys. 6-7. 
a)
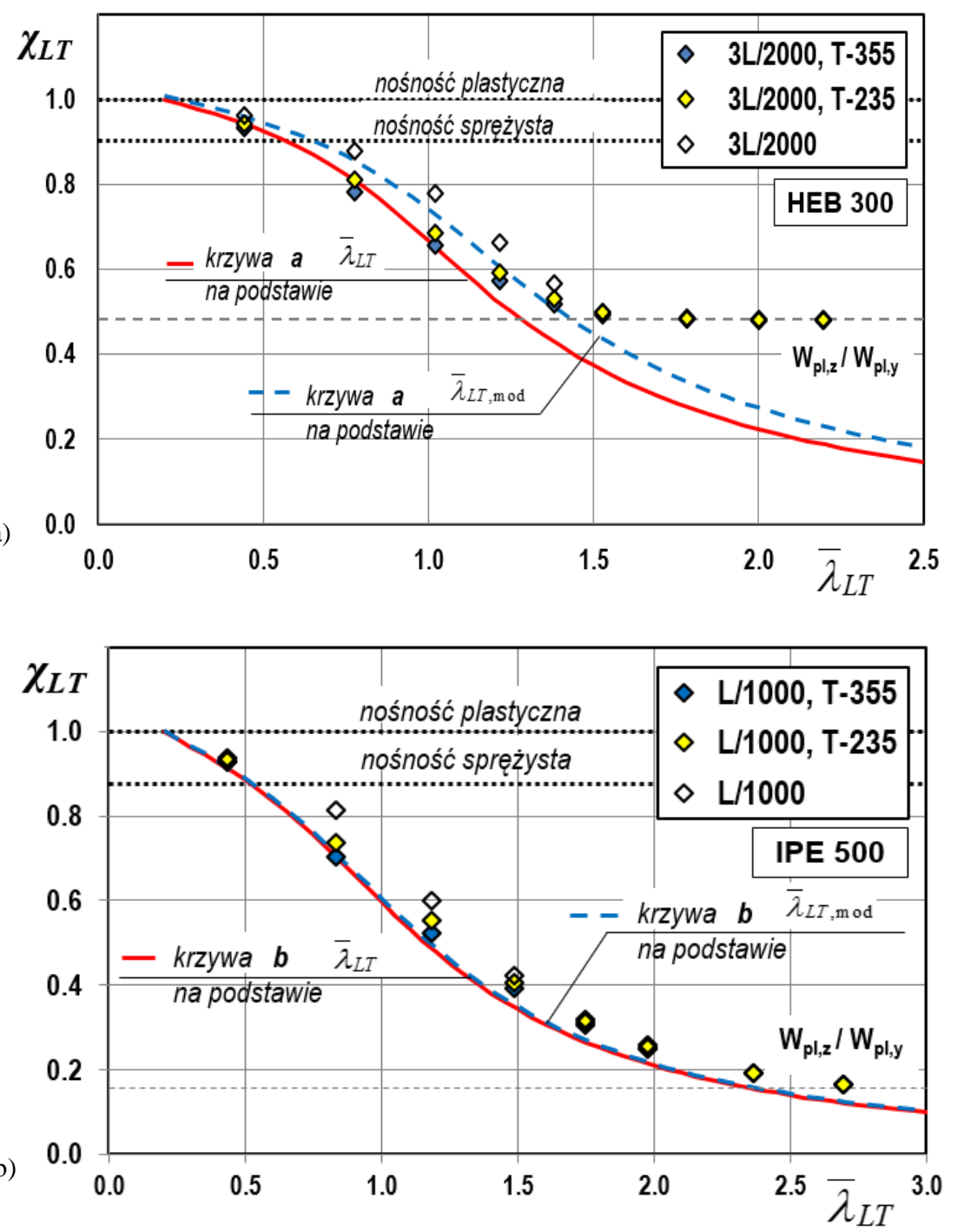

Rys. 6. Porównanie wyników symulacji numerycznych, uwzględniających rozdzielnie imperfekcji materiałowych i geometrycznych, z krzywymi eurokodowymi w przypadku stali S355; a) przekrój HEB 300; b) przekrój IPE $500\left(f_{y, r e f}=355 \mathrm{~N} / \mathrm{mm}^{2}\right.$ i $\left.235 \mathrm{~N} / \mathrm{mm}^{2}\right)$

Fig. 6. Comparison of results of finite element simulations according to the method of separate imperfection inclusion and Eurocode's buckling curves in case of steel S355; a) HEB 300 section; b) IPE 500 section $\left(f_{y, r e f}=355 \mathrm{~N} / \mathrm{mm}^{2}\right.$ and $\left.235 \mathrm{~N} / \mathrm{mm}^{2}\right)$ 

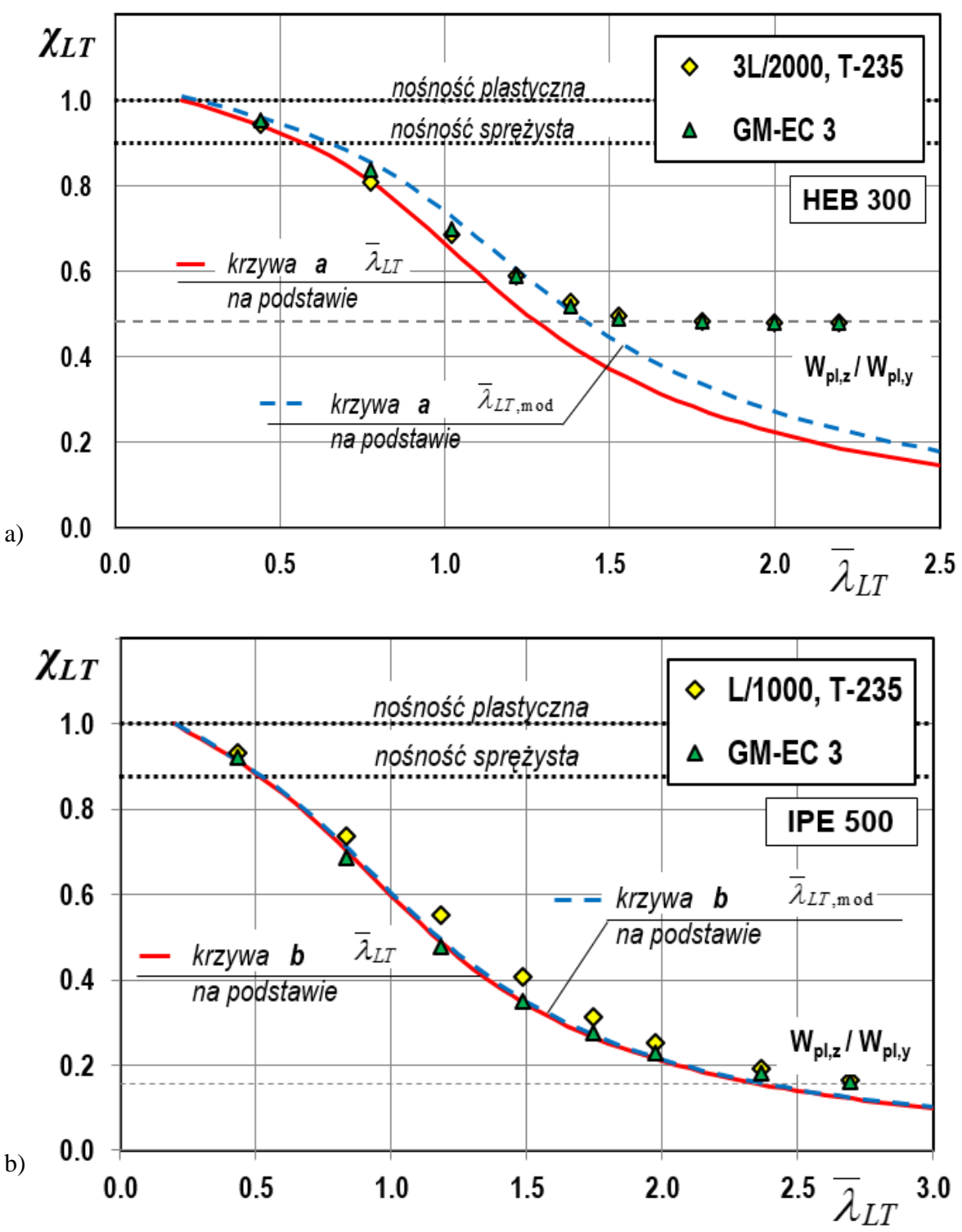

Rys. 7. Porównanie wyników symulacji numerycznych uwzględniających różne metody przyjmowania imperfekcji z krzywymi eurokodowymi w przypadku stali S355; a) przekrój HEB 300; b) przekrój IPE $500\left(f_{y, r e f}=235 \mathrm{~N} / \mathrm{mm}^{2}\right)$

Fig. 7. Comparison of results of finite element simulations according to different methods of imperfection inclusion and Eurocode's buckling curves in case of steel S355; a) HEB 300 section; b) IPE 500 section $\left(f_{y, r e f}=235 \mathrm{~N} / \mathrm{mm}^{2}\right)$ 
Na podstawie wyników przedstawionych na rys. 6-7 można sformułować następujące wnioski:

- bez względu na sposób modelowania imperfekcji, wyniki uzyskane z analiz GMNIA są zbliżone do eurokodowych krzywych zwichrzenia,

- przyjęta wartość referencyjnej granicy plastyczności $f_{y, \text { ref }}$ ma istotny wpływ na nośność dwuteowych elementów zginanych podlegających zwichrzeniu,

- odnośnie elementów o przekroju HEB 300, przyjęcie imperfekcji zastępczych prowadzi do uzyskania nieco wyższych nośności, niż w przypadku rozdzielnego uwzględnienia imperfekcji materiałowych i geometrycznych,

- w przypadku prętów o przekroju IPE 500, symulacje numeryczne uwzględniające rozdzielnie imperfekcje materiałowe i geometryczne prowadzą do uzyskania większych nośności na zwichrzenie, niż zastosowanie imperfekcji zastępczych (odwrotnie niż w przypadku przekroju HEB 300),

- w zakresie średnich smukłości elementów zginanych, naprężenia rezydualne prowadzą do większej redukcji nośności niż imperfekcje geometryczne wynikające $\mathrm{z}$ tolerancji ich wytwarzania,

- odnośnie elementów bardzo smukłych, rozwiązania przy wykorzystaniu MES dążą asymptotycznie do pewnego poziomu współczynnika redukcyjnego nośności przy zwichrzeniu, mianowicie $\chi_{L T} \rightarrow W_{p l, z} / W_{p l, y}$,

- w analizie elementów o przekroju szerokostopowym (HEB 300), rozwiązania numeryczne uzyskane $\mathrm{z}$ analiz GMNIA są bliższe wartościom odpowiadającym eurokodowej krzywej zwichrzenia bazujacej na smukłości zmodyfikowanej $\bar{\lambda}_{L T \text {,mod }}$, a nie smukłości $\bar{\lambda}_{L T}$,

- w przypadku przekroju wąskostopowego (IPE 500), rozwiązania numeryczne uzyskane z analiz GMNIA odpowiadają wartościom eurokodowej krzywej zwichrzenia bazujacej na smukłości $\bar{\lambda}_{L T}$.

\section{Symulacje MES zwichrzenia belek spawanych}

Obliczenia nośności belek jednokierunkowo zginanych względem osi $y$-y ze zwichrzeniem wykonano także w odniesieniu do elementów spawanych o przekrojach HW 300 oraz IW 500. Analizy GMNIA przeprowadzono w odniesieniu do stali konstrukcyjnej S355 oraz metody spawania MAG, stosując podejście wykorzystujące zastępczą imperfekcję geometryczną oraz podejście polegające na niezależnym modelowaniu imperfekcji geometrycznych oraz materiałowych, wynikających z procesu wytwarzania oraz tolerancji wykonania realnych elementów konstrukcji stalowych. Rezultaty symulacji numerycznych porównano z krzywymi eurokodowymi na rys. 8-9.

Na podstawie wyników przedstawionych na rys. 8-9 można sformułować podobne wnioski jak w przypadku analiz przeprowadzonych $\mathrm{w}$ odniesieniu do belek walcowanych na gorąco, których wyniki przedstawiono na rys. 6-7. 

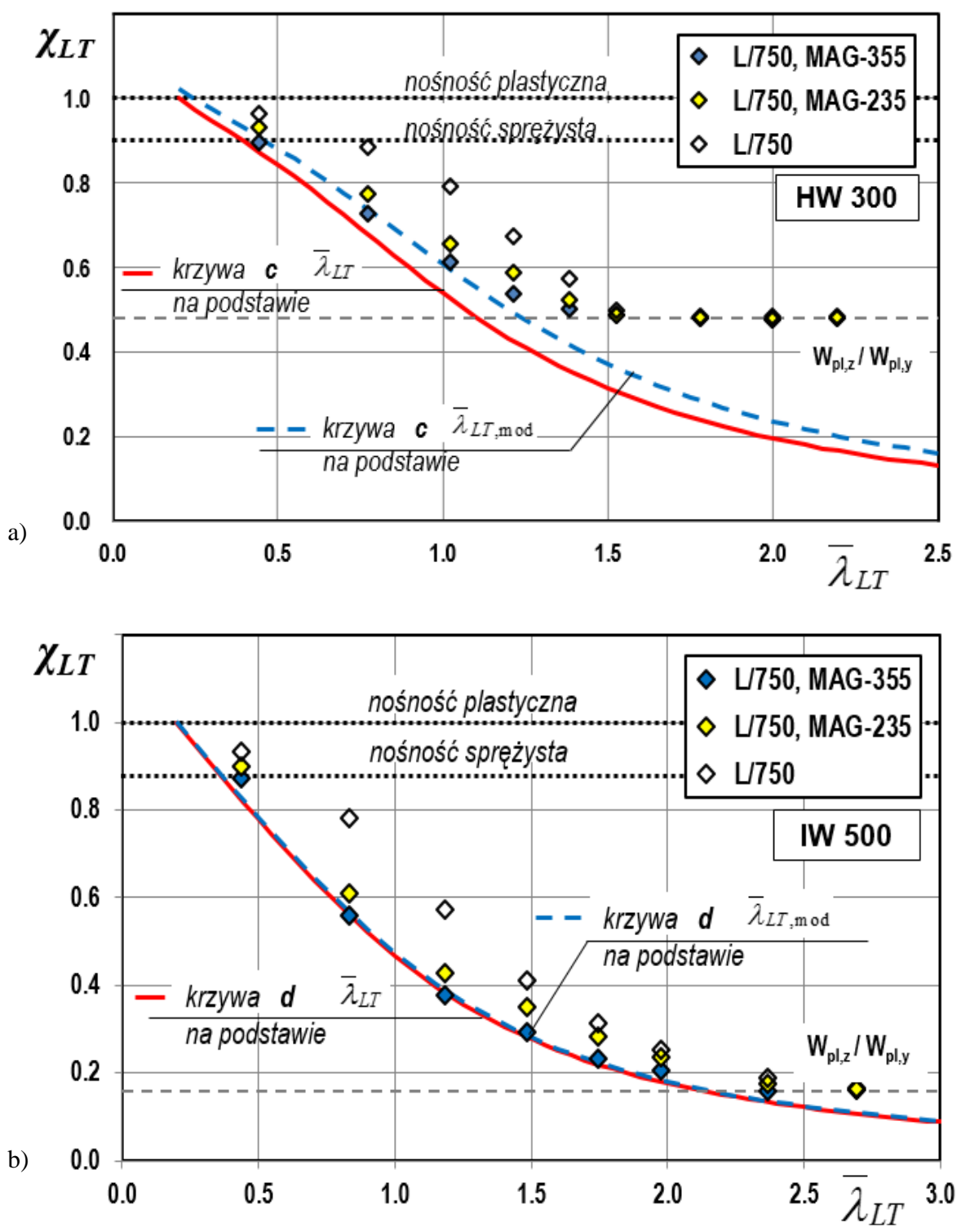

Rys. 8. Porównanie wyników symulacji numerycznych, uwzględniających rozdzielnie imperfekcje materiałowe i geometryczne, z krzywymi eurokodowymi w przypadku stali S355; a) przekrój HW 300; b) przekrój IW 500

Fig. 8. Comparison of results of finite element simulations according to the method of separate imperfection inclusion and Eurocode's buckling curves in case of steel S355; a) HW 300 section; b) IW 500 section 


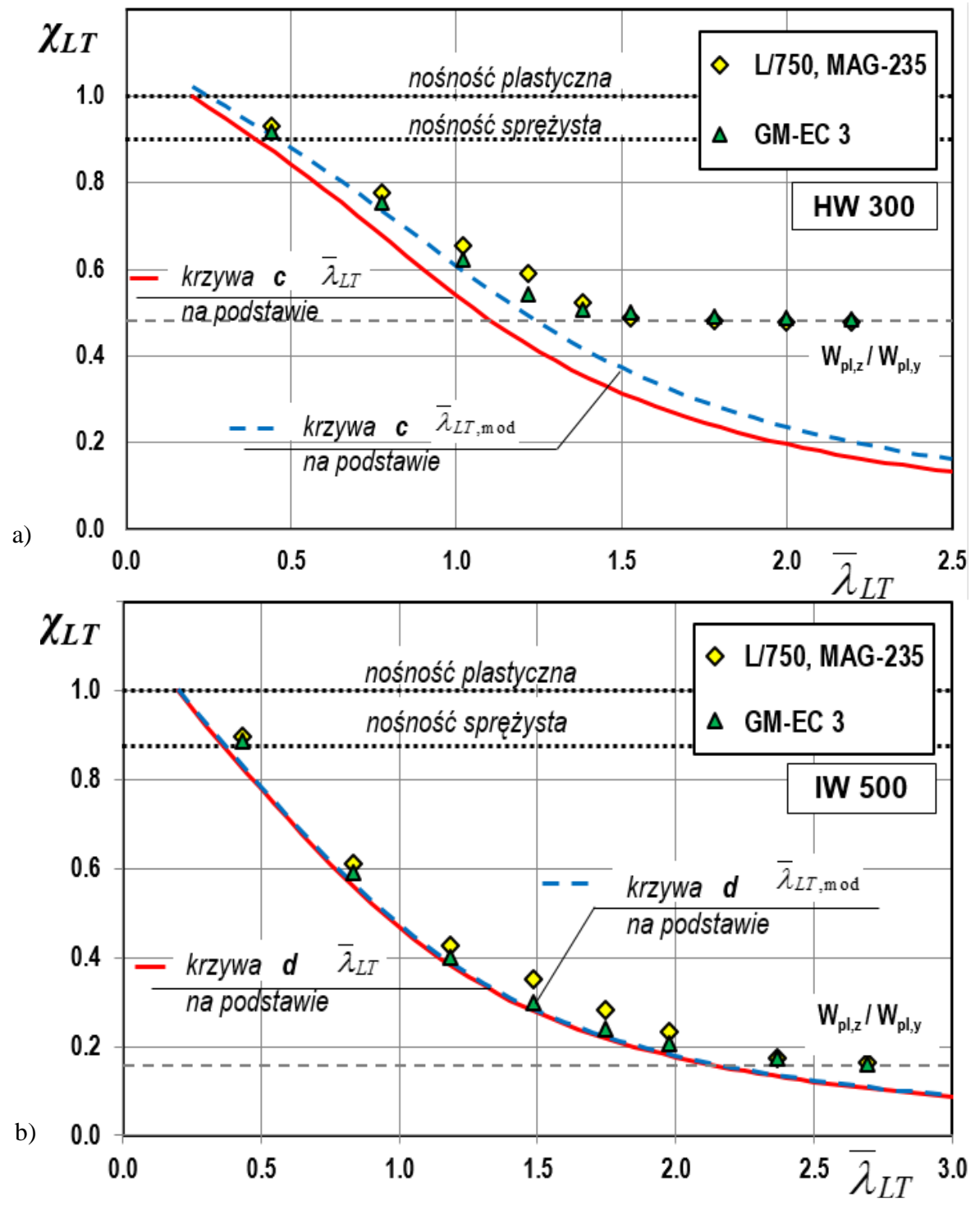

Rys. 9. Porównanie wyników symulacji numerycznych uwzględniających różne metody przyjmowania imperfekcji z krzywymi eurokodowymi w przypadku stali S355; a) przekrój HW 300; b) przekrój IW $500\left(f_{y, r e f}=235 \mathrm{~N} / \mathrm{mm}^{2}\right)$

Fig. 9. Comparison of results of finite element simulations according to different methods of imperfection inclusion and Eurocode's buckling curves in case of steel S355; a) HW 300 section; b) IW 500 section $\left(f_{y, r e f}=235 \mathrm{~N} / \mathrm{mm}^{2}\right)$ 
Na podstawie wyników przedstawionych na rys. 8 i 9 można sformułować następujące wnioski:

- bez względu na sposób modelowania imperfekcji, wyniki uzyskane z analiz GMNIA układają się w pobliżu eurokodowych krzywych zwichrzenia,

- wartość referencyjnej granicy plastyczności $f_{y, r e f}$ ma większy wpływ na techniczne zwichrzenie spawanych elementów zginanych o przekroju bisymetrycznym niż odnotowano to w odniesieniu do elementów walcowanych na gorąco,

- odnośnie elementów spawanych o różnej proporcji wymiarów ścianek przekroju, nośności uzyskane przy użyciu MES z rozdzielnym uwzględnieniem imperfekcji materiałowych i geometrycznych są w całym analizowanym zakresie smukłości większe od nośności uzyskanych przy zastosowaniu imperfekcji zastępczych; uwaga powyższa dotyczy zarówno belek spawanych o przekroju HW 300, jak również belek o przekroju IW 500,

- w zakresie średnich smukłości elementów zginanych, przyjęcie referencyjnej wartości $f_{y, \text { ref }}$ do określenia wartości naprężeń rezydualnych w przekroju spawanym ma istotniejszy wpływ na zwichrzenie niż w wypadku elementów walcowanych na gorąco,

- odnośnie elementów bardzo smukłych, rozwiązania przy wykorzystaniu MES dążą asymptotycznie do tego samego poziomu współczynnika redukcyjnego nośności przy zwichrzeniu, mianowicie $\chi_{L T} \rightarrow W_{p l, z} / W_{p l, y}$, jaki otrzymano w wypadku analiz MES dotyczących belek walcowanych na gorąco,

- podobnie jak w przypadku elementów walcowanych na gorąco, uzyskane $\mathrm{z}$ analiz GMNIA nośności belek spawanych o przekroju szerokostopowym (HW 300) są bliższe wartościom odpowiadającym eurokodowej krzywej zwichrzenia bazujacej na smukłości zmodyfikowanej $\bar{\lambda}_{L T \text {,mod }}$, a nie smukłości $\bar{\lambda}_{L T}$,

- w przypadku belek spawanych o przekroju wąskostopowym (IW 500), rozwiązania numeryczne uzyskane $\mathrm{z}$ analiz GMNIA są bliższe wartościom wyznaczonym z eurokodowej krzywej zwichrzenia bazujacej na smukłości $\bar{\lambda}_{L T}$.

\section{Wnioski}

W pracy przedstawiono zagadnienie wpływu imperfekcji na zwichrzenie techniczne belek stalowych walcowanych oraz spawanych. Przy odrębnym modelowaniu imperfekcji materiałowych (naprężenia resztkowe) oraz geometrycznych (zgodnie z tolerancjami wytwarzania elementów) wyznaczono wpływ typu niedoskonałości na nośność rozważanego elementu. Autorzy zastosowali także podejście polegające na obliczaniu belek obarczonych zastępczą imperfekcją geometryczną stwierdzając, że oba podejścia są na ogół równoważne. Na podstawie przeprowadzonych analiz można ponadto wyciągnąć wniosek, iż w zakresie średnich smukłości elementów zginanych, naprężenia rezydualne 
prowadzą do większej redukcji nośności niż imperfekcje geometryczne wynikające $\mathrm{z}$ tolerancji ich wytwarzania.

Przedstawione w pracy obliczenia jednoprzęsłowych belek o wyidealizowanych warunkach brzegowych są podstawą do przeprowadzenia dalszych analiz, z uwzględnieniem innych warunków brzegowych, np. jak rozważano to w pracy [10], a także z uwzględnieniem złożonych stanów obciążeń [11]. Zastosowana metodologia może być także $\mathrm{z}$ powodzeniem użyta do modelowania zagadnień niestateczności lokalnej i globalnej prętów cienkościennych, jak rozważano np. w [12].

\section{Literatura}

[1] PN-EN 1993-1-1: Eurokod 3 - Projektowanie konstrukcji stalowych. Część 1-1: Reguły ogólne i reguły dla budynków.

[2] Simoes da Silva L., Simoes R., Gervasio H.: Design of Steel Structures, Eurocode 3: Design of steel structures, Part 1-1: General rules and rules for buildings. ECCS Eurocode Design Manual, Ernst \& Sohn, 2010.

[3] Rykaluk K.: Zagadnienia stateczności konstrukcji metalowych, Dolnośląskie Wydawnictwo Edukacyjne, Wrocław 2012.

[4] Pasternak H., Launert B., Krausche T.: Welding of girders with thick plates - Fabrication, measurement and simulation, Journal of Constructional Steel Research, 115, 2015, pp. 407-416.

[5] EN 10034, Structural steel I and H sections- Tolerances on shape and dimensions, CEN, Brussels, 1996.

[6] PN-EN 1090-2, Wykonanie konstrukcji stalowych i aluminiowych - Część 2: Wymagania techniczne dotyczące wykonania konstrukcji stalowych, PKN, Warszawa, 2014.

[7] Giżejowski M., Szczerba R., Gajewski M., Stachura Z.: On the resistance evaluation of lateral-torsional buckling of bisymmetrical I-section beams using finite element simulations, Procedia Engineering 153, 2016, pp. 180-188.

[8] Giżejowski M., Szczerba R., Gajewski M.: Modele MES i metody symulacji w analizie zwichrzenia zginanych elementów konstrukcji stalowych. Czasopismo Inżynierii Lądowej, Środowiska i Architektury - Journal of Civil Engineering, Environment And Architecture, JCEEA, Politechnika Rzeszowska, t. XXXIII, 33, 63 (1/I/16), s. 339-346, DOI: $10.7862 / \mathrm{rb} .2016 .40$.

[9] Giżejowski M., Gajewski M., Stachura Z., Szczerba R.: W sprawie oceny zwichrzenia stalowych belek dwuteowych. Inżynieria i budownictwo, 1/2017, s. 13-17.

[10] Żmuda J.: Problemy niestateczności w projektowaniu dźwigarów stalowych. Studia i Monografie, nr 156, Oficyna Wydawnicza Politechniki Opolskiej, Opole 2004.

[11] Kowal Z., Szychowski A.: Nośność graniczna prętów ściskanych pod interakcyjnym obciążeniem poprzecznym, Inżynieria i Budownictwo, 7, 1996.

[12] Szychowski A.: A theoretical analysis of the local buckling in thin-walled bars with open cross-section subjected to warping torsion, Thin-Walled Structures 76 2014, pp. $42-55$. 


\section{INFLUENCE OF IMPERFECTIONS ON LTB RESISTANCE OF STEEL ROLLED AND WELDED BEAMS}

\section{S u m m a r y}

The proposed paper analyzes the influence of geometrical and material imperfections on the LTB resistance of steel rolled and welded I-section beams subjected to uni-directional bending about major principal axis $y$ - $y$. FEM calculations were conducted in case of rolled beams with wide flange HEB and narrow flange IPE sections and welded beams made of equivalent section dimensions. Imperfection profile corresponding to the lowest eigenmode of lateral-torsional buckling was used in case of equivalent geometric imperfection modelling and the lowest of flexural buckling about minor principal axis $z-z$ in case of separate modelling of geometric and material imperfections. In the latter case, residual stresses were modelled with use of initial stress fields. Geometrically and materially nonlinear analyses of GMNIA type were carried out.

Keywords: steel rolled and welded sections, residual stresses, geometrical imperfections, lateraltorsional buckling, FEM, GMNIA

Przestano do redakcji: 11.04 .2017 r.

Przyjęto do druku: 01.09.2017 r. 